\title{
The Effectiveness of Group Guidance with Modeling Techniques to Improve Students Motivation Learning
}

\author{
Nuri Shofiah $^{\left.1^{*}\right)}$, Suhendri ${ }^{2}$, Farikha Wahyu Lestari ${ }^{3}$ \\ ${ }^{123}$ Fakultas Ilmu Pendidikan Universitas PGRI Semarang \\ *Corresponding author, e-mail: nurishofiah2@gmail.com
}

Received 2020-03-10;

Revised 2020-05-13;

Accepted 2020-05-14;

Published Online 2020-05-30

\section{Conflict of Interest \\ Disclosures: \\ The authors declare that they \\ have no significant competing \\ financial, professional or \\ personal interests that might have \\ influenced the performance or \\ presentation of the work \\ described in this manuscript.}

\begin{abstract}
This research is motivated because of low learning motivation shown by sleepy behavior during class hours, often forgetting assignments given by the teacher, cheating on friends' work, less attractive to him in doing assignments, difficulty understanding lessons, learning if there are exams or tests, discouraging each face difficulties. This research was conducted quantitatively in a quasi-experimental design with the form of a pretestposttest control group design. The population in this study were all students of class XI Kesatrian 2 Semarang High School. Samples taken in this study were 34 students of class XI IPS 3 which were divided into two groups, namely the experimental group of 17 students and the control group of 17 students. With the determination of research subjects using simple random sampling techniques. The data of this study were obtained through a psychological scale of learning motivation. Then the modeling guidance services provided by the modeling technique are on target and on the right material. This is because students after getting a modeling technique group guidance services can apply effective study habits, able to increase enthusiasm in achieving learning goals. Suggestions for supervising teachers are expected to help the supervising teacher to find out student competencies in enhancing learning motivation.
\end{abstract}

Keywords: Learning motivation, group, Modeling techniques

\section{Introduction}

Education is a conscious effort or interaction between educators and students to achieve educational goals. The purpose of education is to help develop the potential, abilities, and personal characteristics of students. Education takes place in schools as a formal institution as a means of achieving these educational goals. Through schools, students learn various things that they will need to develop their potential. According to Sukmadinata (2004: 9-11). 
One of the ways to develop students' potential is to increase learning motivation. The existence of the learning motivation of students as a change, encouragement, and as a stimulus from within someone doing something. according to Soemanto (in Danarjati, 2014: 29), it is hoped that in every educational institution it can produce students who have the motivation to learn. However, based on the reality in the field most students are not fully aware of the importance of learning motivation.

Learning motivation according to Winkel (in Sumantri 2015: 379) is an important role in learning to motivate students to learn who is motivated to have a lot of energy to carry out learning activities. While learning according to Slameto (in Danarjati, 2014: 41) is a process of behavior change that is done by someone new as a whole as a result of his experience in interactions with his environment.

Through this motivation, a person can increase enthusiasm in learning. motivation according to Syamsu (in Saefullah, 2012: 290) motivation is all the power and drive of someone internal in a person, which causes someone to do something and have certain goals. Meanwhile, according to Winkel (in Saefullah, 2012: 291) motivation is a motive in a person who is active before that person does an action and sets goals. According to Asnawi (in Sumantri 2015: 374) motivation is an impulse in a person to act and to inspire someone so that their desires and wishes arise, to do something.

In reality, the data obtained, which occurs in students in SMA Kesatrian 2 class XI there are still many who have low motivation to learn as if learning often sleepy, learn if there will be a test or exam alone, often forget the assignments given by the teacher, less attractive to him in doing assignments, still lazy to do school work, chatting with friends when the learning process takes place, cheating on his friend's work. The results of observation, researchers observed several students, such as students being passive when the teacher gave questions, did not dare to ask when having difficulties, like daydreaming and lack of critical thinking late to class, not confident to go to the front of the class, not participating when discussing, lazy come to school, chat with friends during class time, do not concentrate when the teacher teaches.

Also, based on the results of the AKPD in terms of the topic of learning these results can be seen the percentage of several items, among others, I have not been able to become an independent person $(1.74 \%)$, I do not understand how to choose a good tutoring institution (1.49), I learned if there will be only tests or exams (1.24\%), I feel lazy to study and when studying often sleepy (1.08\%).

While the results of interviews with BK teachers, said that in class XI there are still many who have low learning motivation, namely some students often forget the tasks given by the teacher, are still lazy to do school work, are less attractive to him in doing assignments, still procrastinate, not doing the job properly and on time. And from the description of the problem of low motivation to learn the need for efforts to overcome this problem. Efforts include providing group guidance services through modeling techniques.

In response to this, students need to understand the importance of self-motivation to continue learning, because the motivation to learn will inspire students to stay enthusiastic in learning. conversely, without the motivation students will find it difficult to understand the material that has been explained by the teacher. For example, many students spend sleep during class hours, students ignore the teacher's explanation.

To increase learning motivation with modeling techniques through group guidance services. This is reinforced from the results of Saptono's research $(2016: 211)$ it can be concluded that strong learning motivation will make him more active in learning, full of enthusiasm for learning achievement while for those not motivated to learn will be otherwise lazy to learn, do not have the enthusiasm to achieve learning achievement. So with motivation to learn has an important role for students in the learning process and can provide enthusiasm for learning, motivated to carry out learning activities.

Supported by Yuniarwati's research results (2018: 10) in class XI Aph students of SMK N 1 Cepu, concluded that group guidance through modeling methods can increase learning motivation. According to Albert Bandura (in Gunarsa, 2007: 220-221) modeling is a method of learning by experiencing or paying attention to the behavior of others. Through observations from others and changes in the model for their behavior, the particular model of behavior that the client will emulate should be positive and following client goals. 
Based on various problems that exist in Kesatrian 2 Semarang High School, it is needed an effort that can increase student motivation, therefore the authors are interested in conducting research under the title Effectiveness of Group Guidance Services with Modeling Techniques to Improve Learning Motivation.

\section{Method}

The method used in this study is a quasi-experimental design. According to Sugiyono (2017: 116) states, this design is almost the same as the pretest-posttest control group design, only in this design, the experimental group and the control group are not randomly selected. The purpose of this research is whether group guidance services are effective to increase learning motivation and how to influence after giving modeling techniques with group guidance services to increase student motivation in class XI Kesatrian 2 Semarang High School. This research was conducted at Kesatrian 2 High School Semarang. The population in this study was class XI students, amounting to 206 students. The sample used consisted of one class, namely class XI IPS 3 students, which were divided into two groups: 17 experimental groups and 17 control groups. The technique used is simple random sampling according to Sugiyono (2017: 118) simple random sampling, namely taking sample members from the population carried out randomly without showing strata in the population considered homogeneous.

Sampling in this study can be done by lottery or randomly performed without showing strata that exist in the population considered homogeneous. Then the class taken was IPS 3 class XI which was taken as a sample in the study and divided into the experimental group and the control group.

\section{Results and Discussion}

Based on the calculation of the hypothesis test statistical table analysis for a significant level of 0.05 with a df 33 of 2,042. Based on the calculation of the hypothesis test with the SPSS 15.0 for Windows program, it is known $t=3.037$. Because the number of $t_{\text {count }}>t_{\text {table }}$ then Ho is rejected Ha is accepted, which means that effective group guidance services to improve student motivation in class XI IPS 3 SMA Kesatrian 2 Semarang.

This study uses a quasi-experimental design with the pretest-posttest control group design. Research data shows that the difference between the average pretest and posttest learning motivation scale of 0.12 . This shows that there is a difference in the average learning motivation between the experimental group that is given group guidance services with modeling techniques and the control group that is not given group guidance services with modeling techniques that are 10.53 .

One effort to improve self-regulation in student learning is by providing modeling technique group guidance services to students of class XI IPS 3 SMA Kesatrian 2 Semarang. In this study, researchers treated 5 times the modeling technique group guidance services to 1 class which was divided into an experimental group consisting of 17 students and 17 control group students who were not given a modeling technique group guidance service. The time needed for each meeting is around 30-40 minutes depending on the topic of the problem being discussed.

The fact that happens to students before treatment is done if students learn often sleepy, learn if there will be a test or exam only, often forget the assignments given by the teacher, less attractive to him in doing the assignment, still lazy to do school work, chatting with his friend during the process teaching-learning takes place, cheating on his friend's work.

Research conducted by researchers provides group guidance services with modeling techniques, during the first treatment most of the conditions of students are relatively diverse because the first time they participated in group guidance activities, researchers had to explain to students several times that the 17 students were taking group guidance activities, enthusiasm for participating in the activities because conducted in the classroom with a comfortable atmosphere and air-conditioned rooms, then students solve 
the problem under the descriptive problem at the first meeting that is discussing the concentration of learning, ending with the ability of students to be able to apply it in everyday life.

Then in the second treatment, the condition of students is relatively diverse because it is done after the second hour of school hours, there are some students who respond well there are those who do not respond well, students solve problems following descriptive problems at the second meeting which discusses learning motivation, some students give real examples of what they experience following the problematic problems, ending with the ability of students to be able to apply it in their daily lives and conduct treatment activities at upcoming meetings.

In the third treatment, the student's condition focuses on service activities, group guidance is carried out in the classroom with acac, students listen to a brief exposure to effective learning by researchers, students solve problems on descriptive problems that have been prepared by researchers by discussing together, some students are confused by the way effective learning like what students have, but some others understand what effective learning methods they use, students respect each other's opinions, ending with the ability of students to recognize effective ways of learning in learning activities so that success in learning can be higher.

In the fourth treatment still using air-conditioned classrooms and a comfortable atmosphere, the activities of this treatment researchers explained verbally how to improve learning habits and recognize learning activities, after oral exposure by the speaker the students solved the problem in descriptive problems that had been prepared by the speaker, namely discussing study habits, students are enthusiastic in participating in activities, ending with the ability of students to start an activity each student can apply learning habits in themselves in learning activities.

At the fifth meeting, some students were not active and some students were active, oral exposure to the topic of problems with modeling techniques, students solved the problem following the descriptive problem prepared by the researcher, students were enthusiastic about giving opinions according to what was being experienced, students told how discipline in learning then ends with the ability of students to better recognize the discipline in learning.

In this fifth treatment, the feedback between researchers and students has been seen. Some students dare to ask questions. At the fifth meeting, most of the students had begun to show their enthusiasm by asking questions and answering questions raised by researchers. So it can be concluded that there is an increase and a good development of overall students in showing their active attitude, student enthusiasm, as well as in terms of understanding and how they apply the material presented in their learning activities and achievement of learning goals.

By using the modeling technique group guidance services can increase learning motivation in student learning, the pretest results indicate an average score of the experimental group 36.18 and the control group 46.59 while the post-test results indicate an average of the experimental group of 36.06 and the control group was 36.06 . So there was an increase in the average in the experimental group by 0.12 .

Here are depicted in table form :

Table 1. Pretest dan postest kelompok eksperimen dan kelompok kontrol

\begin{tabular}{lllllll}
\hline Kelompok & Pretest & & Postest & & $\begin{array}{l}\text { Independent Test } \\
\text { Sig.(2-tailed) }\end{array}$ & Keterangan \\
& M & SD & M & SD & & Significant \\
Eksperimen & 36,18 & 10,2 & 36,06 & 7,44 & 0,004 & Not significant \\
Kontrol & 46,59 & 11,8 & 36,06 & 7,44 & 0,970 & \\
\hline
\end{tabular}

Bisma The Journal Of Counseling, Open Access, https://ejournal.undiksha.ac.id/index.php/bisma 


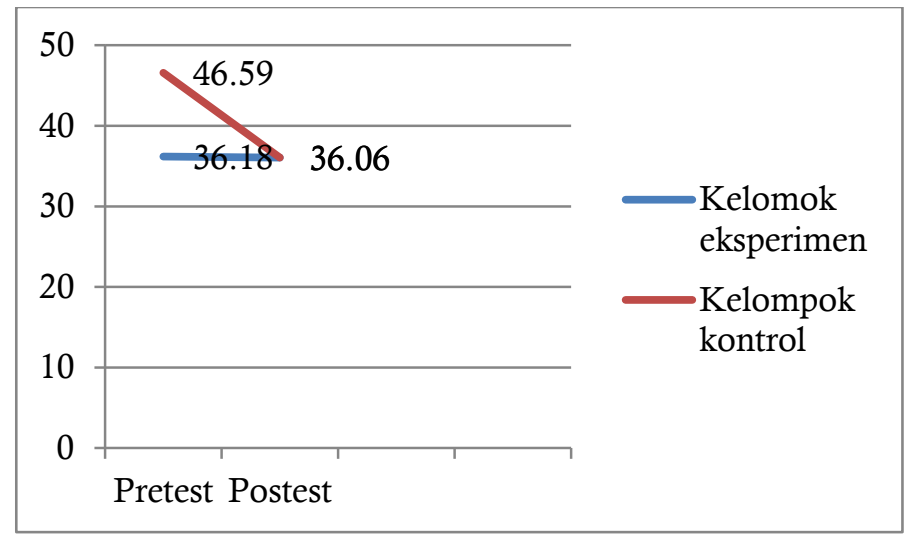

Fig. 1 Pretest dan Postest Kelompok Kontrol dan Kelompok Eksperimen

The difference that occurs in the experimental group and the control group is, because of the treatment or treatment. The experimental group increased after receiving treatment, in contrast to the control group that did not get treatment. This can be seen from the results of treatment carried out to the experimental group as much as 5 times with a total of 17 students routinely conducting group guidance according to the service implementation schedule and students are always all present. This is also supported by the evaluation of the results conducted by researchers after giving a treatment by observing some students who are included in the experimental group shows that there are differences in attitude that is shown that can manage the learning time the value obtained during learning also increases during teaching and learning activities. In addition to observations made by researchers also supported by the results evaluation questionnaire that has been filled out by students as well, in the first treatment the total score of students was quite good, the second treatment was included in the good category too, then in the third treatment the total score of students could be categorized in very good, then in the fourth treatment included in the good category, then the fifth treatment included in the total score of the students categorized in very good condition.

Then the modeling guidance services provided by the modeling technique are on target and on the right material. This is because students after getting a modeling technique group guidance services can apply effective study habits, able to increase enthusiasm in achieving learning goals.

\section{Conclusion}

Based on the results of testing on the first hypothesis by comparing the pretest and posttest scores of the experimental group and the control group where the hypothesis or (Ha) reads "group guidance services with effective modeling techniques to increase learning motivation" is accepted. While the null hypothesis (Ho) reads "group guidance services with ineffective modeling techniques to increase learning motivation" is rejected. Then it can be concluded that group guidance services with effective modeling techniques to increase learning motivation because they have differences.

\section{References}

Arikunto, Suharsimin. (2014). Prosedur Penelitian Suatu Pendekatan Praktik. Jakarta: PT Rineka Cipta. Alwisol. (2012). Psikologi Kepribadian. Malang: UMM Pers.

Amin, Nurul Zakki. (2017). Portofolio Teknik-Teknik Konseling. Semarang: Universitas Negeri Semarang. Corey, Gerald. (2003). Teori dan Praktek Konseling\&Psikoterapi. Bandung: PT Refika Aditama. 
Erford, Bradley T. (2017). 40 Teknik yang harus diketahui setiap konselor edisi kedus. Yogyakarta: Pustaka Pelajar.

Gunarsa, Singgih. (2007). Konseling dan Psikoterapi. Jakarta: PT Ikrar Mandiri Abadi.

Hambali, Adang. (2013). Psikologi Kepribadian lanjutan (Studi Atas Teori Dan Tokoh Psikologi Kepribadian). Bandung: CV Pustaka Setia.

Komalasari, Gantina. (2018). Teori \& Teknik Konseling. Jakarta: PT Indeks Permata Puri Media.

Kompri. (2015). Motivasi Pembelajaran Perspektif Guru dan Siswa. Bandung: PT Remaja Rosdakarya.

Pervin, Lawrence. (2015). Psikologi Kepribadian Teori \& Penelitian Edisi Kesembilan. Jakarta: Prenadamedia Group.

Purnamasari, Lilis Ratna. (2012). Teknik-Teknik Konseling.Universitas Negeri Semarang.

Prayitno. (2017). Konseling Profesional Yang Berhasil. Jakarta: PT Raja Grafindo Persada.

Prayitno dkk. (2017). Layanan Bimbingan Kelompok \& Konseling Kelompok. Bogor: Ghalia Indonesia.

Priyanto, Duwi. (2010). Teknik Mudah dan Cepat Melakukan Analisis Data Penelitian dengan SPSS dan Tanya Jawab Ujian Pendadaran. Yogyakarta: Gava Media.

Priyanto, Duwi.(2012). Belajar Praktis Analisis Parametrik dan Non Parametrik dengan SPSS dan Prediksi Pertanyaan Pendadaran Skripsi dan Tesis. Yogyakarta: Gava Media.

Romlah, Tatiek. (2001). Teori\& Praktek Bimbingan Kelompok. Malang: Universitas Negeri Malang.

Sugiyono. (2017). Metode Penelitian Kuantitatif, Kualitatif dan R\&D. Bandung: Alfabeta.

Sukardi, Dewa Ketut. (2008). Pengantar Pelaksanaan Program Bimbingan dan Konseling di Sekolah. Jakarta: PT Rineka Cipta.

Sumantri, Mohamad Syarif. (2015). Strategi Pembelajaran Teori dan Praktik di Tingkat Pendidikan Dasar. Jakarta: Raja Grafindo Persada.

Syahniar. (2017). The Responsibility of Counselor and Educator in Millennium Era Proceeding Internasional Counseling and Education Seminar ICES 2017. Jurnal Fakultas Ilmu Pendidikan, UNP 2017.

Saptono, Yohanes Joko. (2016). Motivasi dan keberhasilan belajar siswa. Jurnal Pendidikan agama kristen regulasi fidei Volume 1 Nomor 1 Maret 2016.

Sudjana. (2005). Metoda Statistika. Bandung: Tarsito.

Sukarno, Anton dan Venty. (2017). Statistik Pendidikan. Universitas PGRI Semarang

Trihendradi, C. (2009). 7 Langkah Mudah Melakukan Analisis Statistik Menggunakan SPSS 17. Yogyakarta:CV Andi Offset.

Widiasworo, Erwin. (2017). 19 Kiat Sukses Membangkitkan Motivasi Belajar Peserta Didik. Jogjakarta: ARRUZZ Media.

W, Teguh. (2008). Cara Mudah Melakukan Analisa Statistik dengan SPSS (Studi Kasus, Pembahasan dan Teknik Membaca Output). Yogyakarta:Gava Media.

Yuniarwati, Christiyo Tri. (2018). Meningkatkan Motivasi Belajar Melalui Layanan Bimbingan Kelompok dengan Teknik Modeling Pada Siswa Kelas XI Aph SMK N 1 Cepu Semester Gasal Tahun 2017/2018. Jurnal Volume 5 Nomor 1 April 2018 ISSN 2406-8691.

Article Information (Supplementary)

\section{Conflict of Interest Disclosures:}

The authors declare that they have no significant competing financial, professional or personal interests that might have influenced the performance or presentation of the work described in this manuscript.

Copyrights Holder: $<$ Shofiah $><2020>$

First Publication Right: BISMA The Journal of Counseling

http://dx.doi.org/10.23887/bisma.v4i1

Open Access Article | CC-BY Creative Commons Attribution 4.0 International License.

@creative

Word Count: 3318 